\title{
A GIS-Based Drastic Model for Assessing Aquifer Vulnerability in Amman-Zerqa Groundwater Basin, Jordan
}

\author{
Abdulla M. Al-Rawabdeh ${ }^{1}$, Nadhir A. Al-Ansari ${ }^{2 *}$, Ahmed A. Al-Taani ${ }^{3}$, Sven Knutsson ${ }^{2}$ \\ ${ }^{1}$ Department of Geomatics Engineering, University of Calgary, Alberta, Canada \\ ${ }^{2}$ Department of Civil, Environmental and Natural Resources and Engineering, Luleå University of Technology, Luleå, Sweden \\ ${ }^{3}$ UNESCO Chair for Desert Studies and Desertification Control, Yarmouk University, Irbid, Jordan \\ Email: *Nadhir.alansari@ltu.se
}

Received February 1, 2013; revised March 3, 2013; accepted March 12, 2013

Copyright (C) 2013 Abdulla M. Al-Rawabdeh et al. This is an open access article distributed under the Creative Commons Attribution License, which permits unrestricted use, distribution, and reproduction in any medium, provided the original work is properly cited.

\begin{abstract}
Amman-Zerqa Basin (AZB) is a major basin in Jordan. The concentration of economic, agricultural and social activities within the basin makes it of prime importance to Jordan. Intensive agricultural practices are widespread and located close to groundwater wells, which pose imminent threats to these resources. Groundwater contamination is of particular concern as groundwater resources are the principal source of water for irrigation, drinking and industrial activities. A DRASTIC model integrated with GIS tool has been used to evaluate the groundwater vulnerability of AZB. The Drastic index map showed that only $1.2 \%$ of the basin's total area of $3792 \mathrm{~km}^{2}$ lies in the no vulnerable zone and about $69 \%$ is classified as having low pollution potential. The results also revealed that about $30 \%$ of the catchment area is moderately susceptible to pollution potential and slightly $1 \%$ is potentially under high pollution risk. These results suggest that almost one third of the AZB is at moderate risk of pollution potential. These areas are mainly in the north-east and central parts of the basin where the physical factors (gentle slope and high water table) would allow more contaminants to easily move into the shallow groundwater aquifer. Areas with high vulnerability to pollution are largely located in the center of Amman old city.
\end{abstract}

Keywords: Amman-Zerqa Basin; Jordan; GIS; DRASTIC

\section{Introduction}

Water shortage in Jordan has long been identified as a critical constraint to its future development and the single most challenge to next generation. While severe droughts in Jordan have persisted, the pressures and competition over the available water resources are mounting every year. Jordan relies heavily on groundwater to meet the rising demands for water. In addition to overdraft and quantity issues, groundwater sources are threatened by contamination through human activities. Among others, excessive use of fertilizers and pesticides, unregulated discharge of natural and artificial chemical substances, and improper management of aquifers remain of critical importance.

The Amman-Zarqa Basin (AZB) is a major hydrological basin in Jordan, which is located in the transitional area between the western highlands and the eastern desert. This

${ }^{*}$ Corresponding author. is not only reflected by the climatic variations (from wet to dry), but also by different land use patterns and large changes of habitat. While the western hilly areas are relatively densely populated, the southeast of the basin is fully desert and occupied by small communities of nomads. However, more than $60 \%$ of the country's population lives in this basin $[1,2]$. The basin has witnessed a sudden expansion in urban development and currently hosts about $70 \%$ of Jordan's industrial activities. In addition, unsustainable agricultural practices are widespread. Irrigated agriculture is essentially concentrated around groundwater wells and along the Zerqa River banks, whereas rainfed farming is distributed in high rainfall areas. The remaining area of the basin is covered by sporadic vegetation (used normally for grazing), bare and rocky areas, and forests. As a result of the unplanned and uncontrolled development in the basin, various environmental issues have recently emerged, of these are: land degradation and desertification, mining and salinization of groundwater, reduced river base 
flow and deforestation processes. In addition, large wastewater treatment plant (Khirbet As-Samra), which is located at the upper basin and serving the two main cities of Amman and Zerqa, discharges more than $65 \mathrm{MCM}$ of its effluent into the main river contributing about $50 \%$ of its annual yield.

While groundwater water constitutes a significant portion of water resources in Jordan, conservation and protection of these water resources remain of central importance to Jordan. Groundwater vulnerability studies are considerably a new venue for research in Jordan [3-9]. While aquifer vulnerability to pollution can be assessed through several approaches, DRASTIC method, a standardized system for evaluating groundwater pollution potential has been frequently implemented.

This research aims to evaluate the vulnerability of AZB using DRASTIC model. It also intends to examine the combined use of the DRASTIC and geographical information system (GIS) to provide an effective management tool to groundwater quality and vulnerability. This helps in developing strategies for land use management of catchment area and determines highly susceptible areas to contamination for further conservation measures.

\section{Description of the Study Area}

AZB is an especially important basin because it is the largest groundwater basin in Jordan (Figure 1). The Zerqa River is the second main tributary to River Jordan after Yarmouk River. In addition, the concentration of economic, agricultural and social activities within the basin makes it of prime importance to Jordan. The basin comprises an area of about $3918 \mathrm{~km}^{2}$, of which $89 \%$ are located in Jordan, and $11 \%$ is inside the Syrian territory. The basin extends from the upper northern part (at the outlet near King Talal Dam) and encompasses five governorates (Amman, Belqa, Jerash, Mafraq and Zerqa).

Although the basin has a Mediterranean arid to semiarid climate, it includes three sub-climate regions; the western highlands climate (Jerash and Amman) with an annual rainfall ranging between $100 \mathrm{~mm}$ in the south and $600 \mathrm{~mm}$ in the north. Arid conditions prevailing in the eastern basin (Al-Mafraq) with an annual precipitation varying from less than $20 \mathrm{~mm}$ in the southern area to less than $150 \mathrm{~mm}$ eastwards. The central basin, a transitional area (Zerqa), receives an annual rainfall ranging between $50 \mathrm{~mm}$ in the south and $300 \mathrm{~mm}$ in the north (Figure 2). Table 1 summarized the average monthly rainfall and potential evapotranspiration in the basin [10].

\section{Geology of the Study Area}

The geology of the AZB has been fully studied [11-16]. The study area is covered by the Upper and Lower Cretaceous deposits and primarily composed of sandstone, limestone, dolomitic limestone, marl, marly limestone, chert and shale. They belong to the Ajlun and Balqa Groups of Upper Cretaceous and to the Kurnub Group of Lower Cretaceous age [11]. In addition, there are some recent deposits (Wadi-fill and alluvium deposits) of Quaternary age. The geologic outcroppings in the study area are presented in Figure $\mathbf{3}$ and summarized in Table 2.

Table 1. The average monthly rainfall and potential evapotranspiration in the AZB (1970-2000) [10].

\begin{tabular}{|c|c|c|c|c|c|c|c|c|c|c|c|c|}
\hline \multirow{2}{*}{ Parameter } & \multicolumn{12}{|c|}{ Month } \\
\hline & Jan & Feb & Mar & Apr & May & Jun & Jul & Aug & Sep & Oct & Nov & Dec \\
\hline Average Rainfall (mm) & 7.3 & 25.1 & 48.9 & 61.8 & 55.1 & 42.9 & 12.8 & 1.9 & 0.0 & 0.0 & 0.0 & 0.0 \\
\hline Potential Evapotranspiration (mm/d) & 4.2 & 2.5 & 2.3 & 2.1 & 2.6 & 3.9 & 5.7 & 6.8 & 7.6 & 8.1 & 7.2 & 5.6 \\
\hline
\end{tabular}

Table 2. Summary of the major lithostratigraphic units in the AZB area.

\begin{tabular}{|c|c|c|c|c|c|c|}
\hline Period & Epoch & Group & Masri (1963) Parker (1970) & Bender (1974) & Thickness (m) & Brief Description \\
\hline \multirow{9}{*}{ 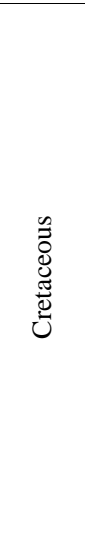 } & \multirow{8}{*}{ 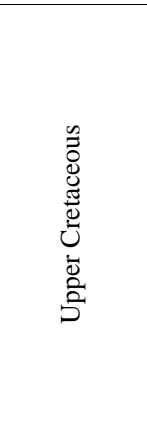 } & \multirow{3}{*}{ Belqa } & Muwagger & Chalk Marl & $60-70$ & $\begin{array}{l}\text { Multi Colored Chalk Marl } \\
\text { interpolated with thin beds of chert }\end{array}$ \\
\hline & & & Amman & $\begin{array}{c}\text { Phosphorite } \\
\text { Silicified Limestone }\end{array}$ & $80-100$ & $\begin{array}{l}\text { Phosphorite, Chalk, Chert, } \\
\text { Massive Limestone }\end{array}$ \\
\hline & & & Wadi Ghudran & Silicified Limestone & 15 & Chalk \& Chalky Marl \\
\hline & & \multirow{5}{*}{ Ajlun } & Wadi Sir (WSL) & Massive L.S & $100-185$ & $\begin{array}{l}\text { Thinly bedded limestone } \\
\text { Chalk limestone with Chert bands }\end{array}$ \\
\hline & & & Shu'eib (SH) & \multirow{2}{*}{ Echinoidal Limestone } & $65-100$ & Marly Limestone, Limestone \& Shale \\
\hline & & & Hummar $(\mathrm{H})$ & & $46-65$ & Dolomitic Limestone \\
\hline & & & Fuheis (F) & \multirow{2}{*}{ Nodular Limestone } & $60-80$ & \multirow{2}{*}{ Marl, Limestone, Marly Limestone and Shale } \\
\hline & & & Na’ur (NL) & & $150-220$ & \\
\hline & $\begin{array}{l}\text { Lower } \\
\text { Cretaceous }\end{array}$ & $\begin{array}{l}\text { Kurnub } \\
\text { (KS) }\end{array}$ & $\begin{array}{l}\text { Subeihi } \\
\text { Arda }\end{array}$ & $\begin{array}{l}\text { Varicoloured Sandstone } \\
\text { White Massive } \\
\text { Sandstone }\end{array}$ & 380 & $\begin{array}{l}\text { Multicolored Sandstone with large proportion } \\
\text { of marl, Clay and Siltstone Yellow White } \\
\text { massive sandstone with shale and dolomite }\end{array}$ \\
\hline
\end{tabular}




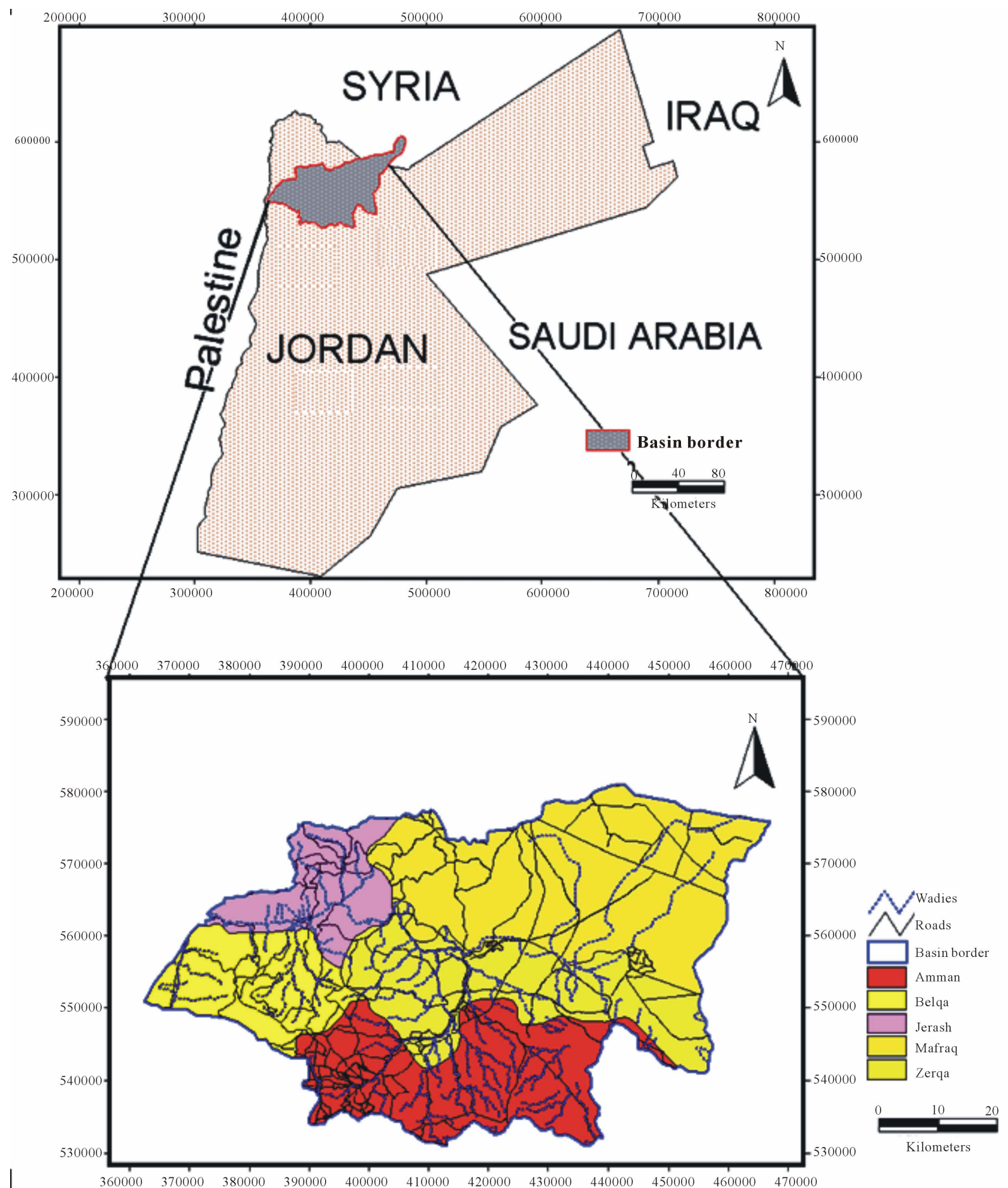

Figure 1. Location map the Amman-Zerqa Basin.

Ajlun group consists of the following Formations (in descending order): Wadi Sir Limeston (WSL), Shu'eib (SH), Hummar (H), Fuheis (F) and Na'ur (NL).

The Belqa Group overlays Ajlun Group and consists mainly of chalk, marl, silicified limestone, chert and phosphates. Masri [11] and MacDonald [12] have subdivided this group into five formations, the first two of which occur in the study area). These are; Wadi Umm Ghudran Formation (WG) consists of a sequence of chalk and chalky marl with a thickness ranging between 15 - $35 \mathrm{~m}$ in north Amman and disappears in other locations. Amman Formation (AHP) consists of limestone with chert interbedded with phosphatic layers and marls. It varies in thickness from $80 \mathrm{~m}$ to $150 \mathrm{~m}$ and is charac- 


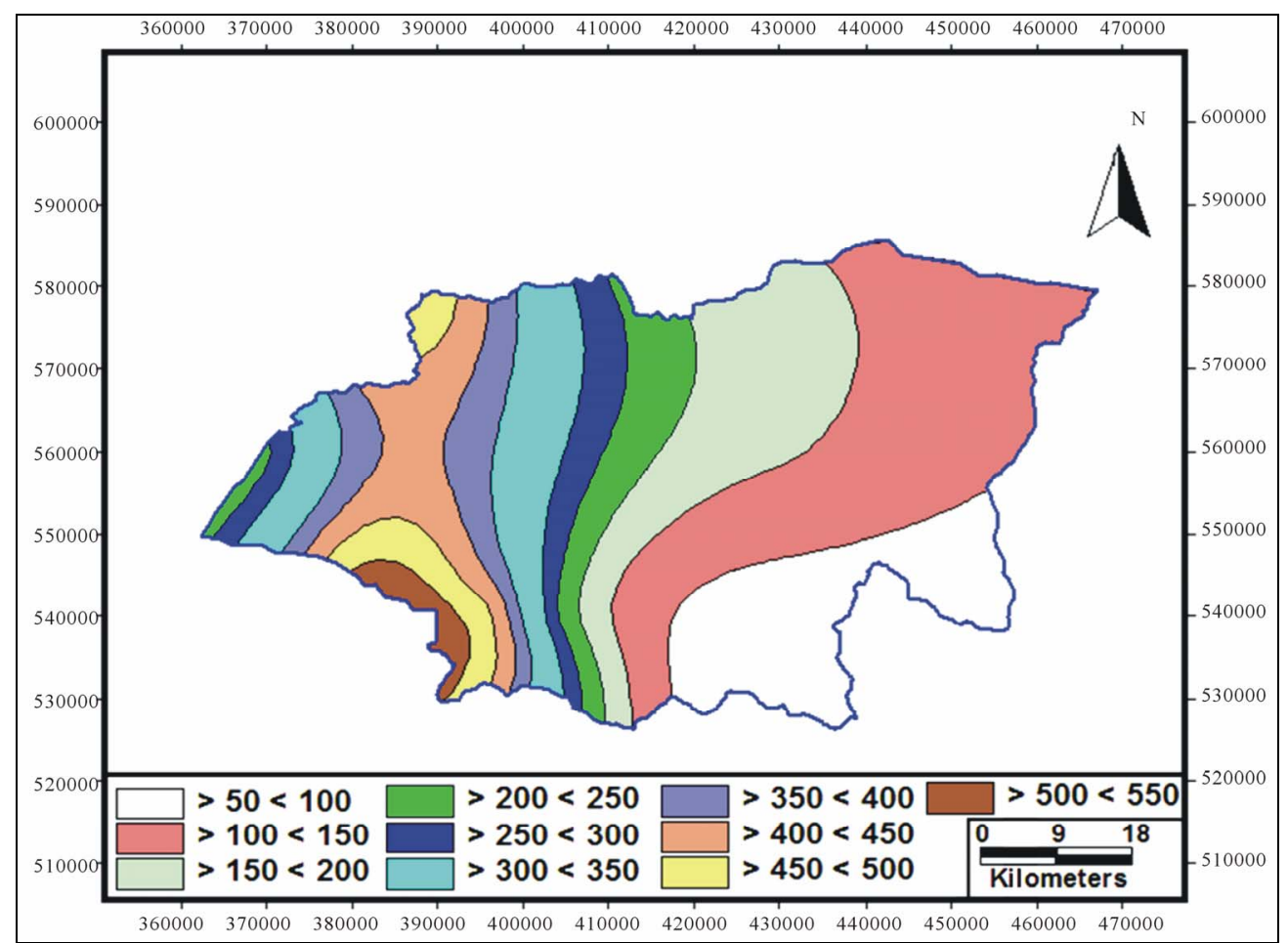

Figure 2. Rainfall distribution in AZB (60 year average).

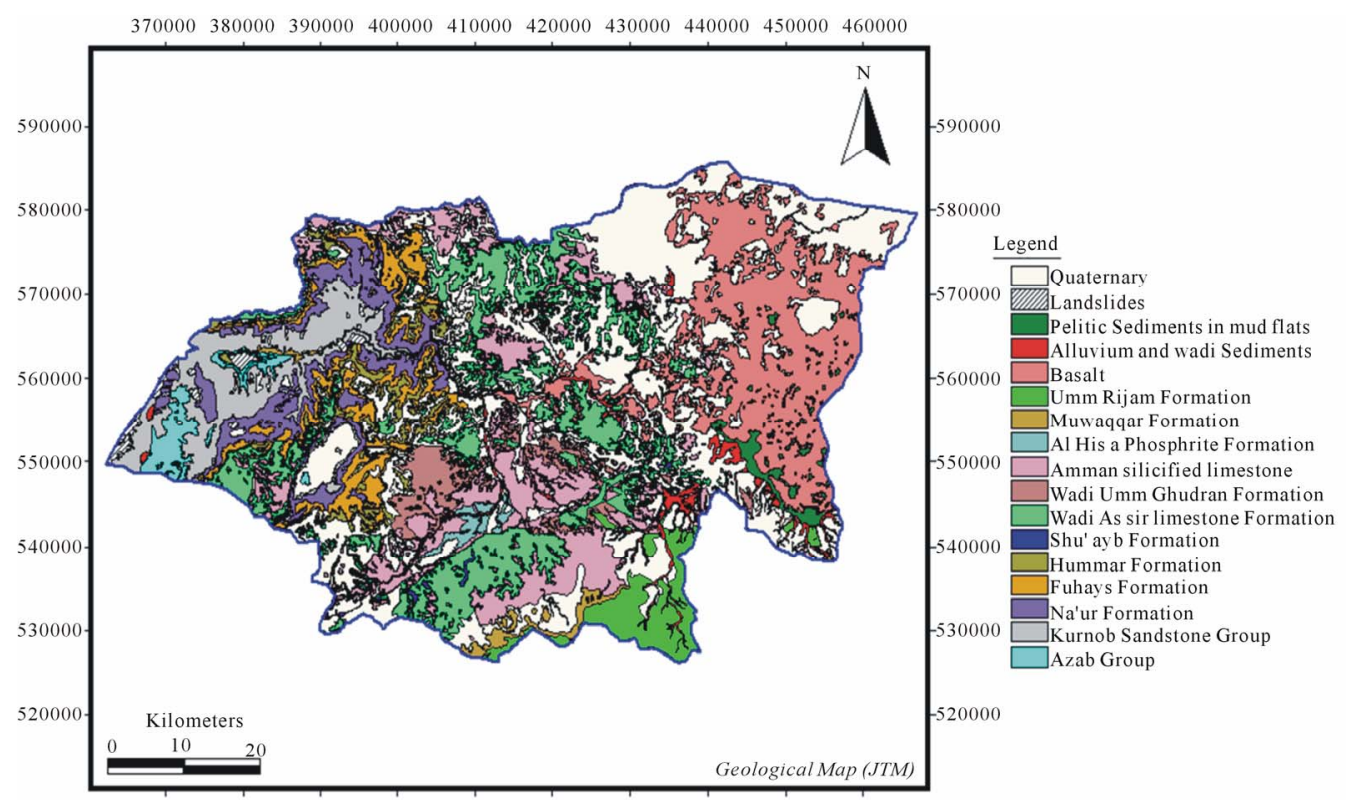

370000380000390000400000410000420000430000440000450000460000

Figure 3. Geological map of the study area (Digitized from jordanian natural resources authority maps 2007).

terized by the presence fracturing and jointing in the chert beds. This formation is subdivided into two units: the lower unit is the Silicified Limestone Unit (B2a) and the upper unit is the Phosphorite Unit (B2b).

In the AZB, several geological structures are related to the Dead Sea Transform fault, including Amman-Zerqa syncline, Amman-Hallabat structure, and Suweileh struc- ture (Figure 4). The major structure is represented by Amman-Zerqa syncline, which extends from south of Amman to the northeast along Zerqa river. Another main structure is the Amman-Zerqa anticline which extends parallel to Amman-Zerqa syncline. Ramtha-Wadi Sirhan fault is a major fault affected the northeastern parts of AZB which is directed northwest-southeast [18]. 


\section{Aquifer Characterization}

The upper Aquifer Complex with a total thickness of about 600 to $700 \mathrm{~m}$ consisting of the limestone and marl complex of the Upper Cretaceous. The groundwater in the upper complex generally moves eastwards. This system consists of three aquifers: the first is alluvial deposits aquifer, which is restricted to the major wadis and plateau gravel deposits, and consists of silts, clays and gravel. It underlies the basalt aquifer occurs between different basalt flows [19]. The basalt aquifer forms the second aquifer and covers most of Wadi Dhuleil and northeastern desert areas. The Amman-Wadi Sir (B2/A7) aquifer overlies Hummar aquifer and comprises two formations: Al-Hisa (B2) and Wadi Es Sir (A7). It consists of chert and limestone, with an average thickness of about $175 \mathrm{~m}$ in the Amman. The groundweater aquifers are presented in Figure 5.

The Middle aquifer system (the late cretaceous aquifers) consists of Hummar (A4) and Na'ur (A1/2) formations. The Upper Cretaceous aquifers within Ajlun and

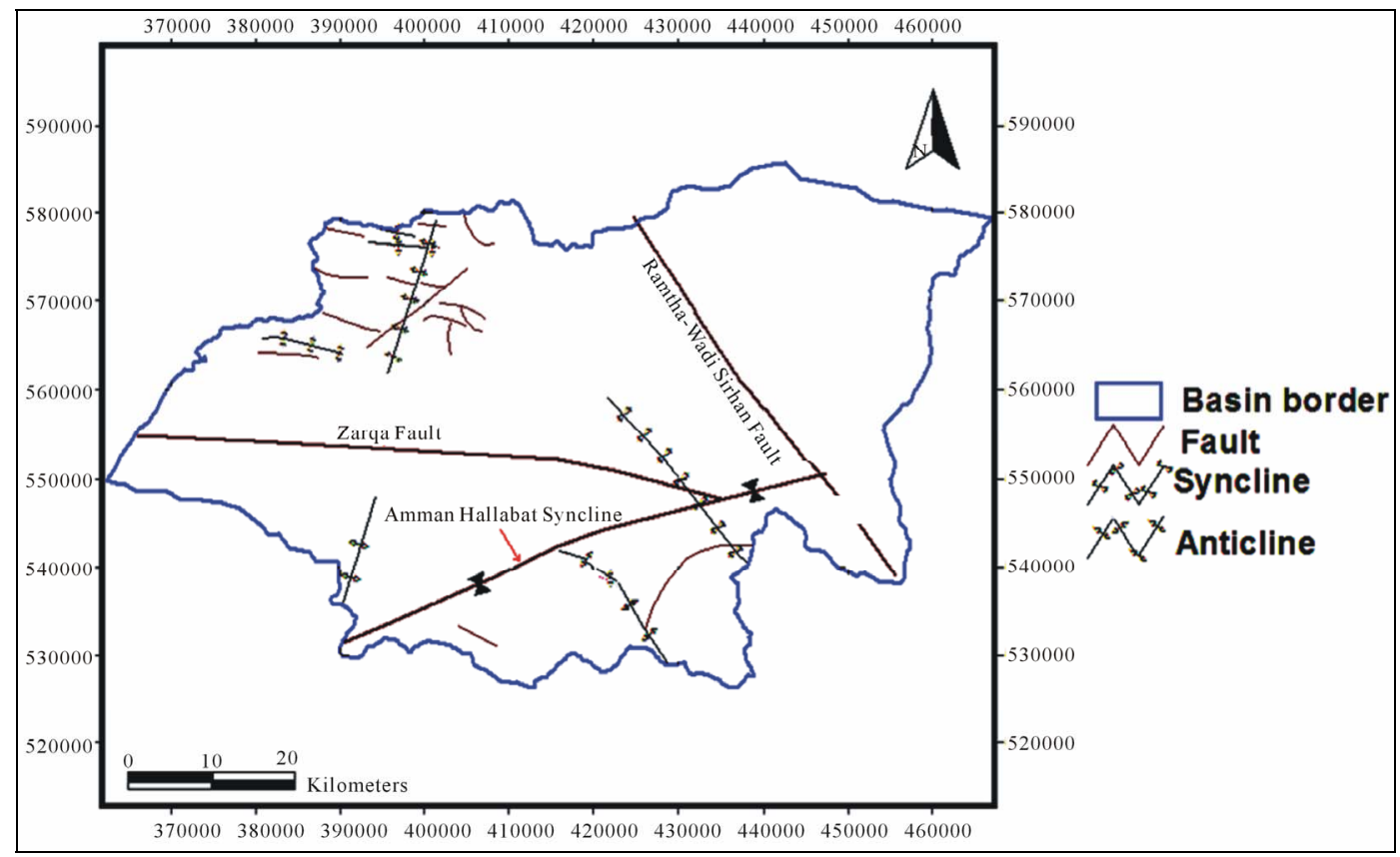

Figure 4. Structural map of the study area (modified after [17]).

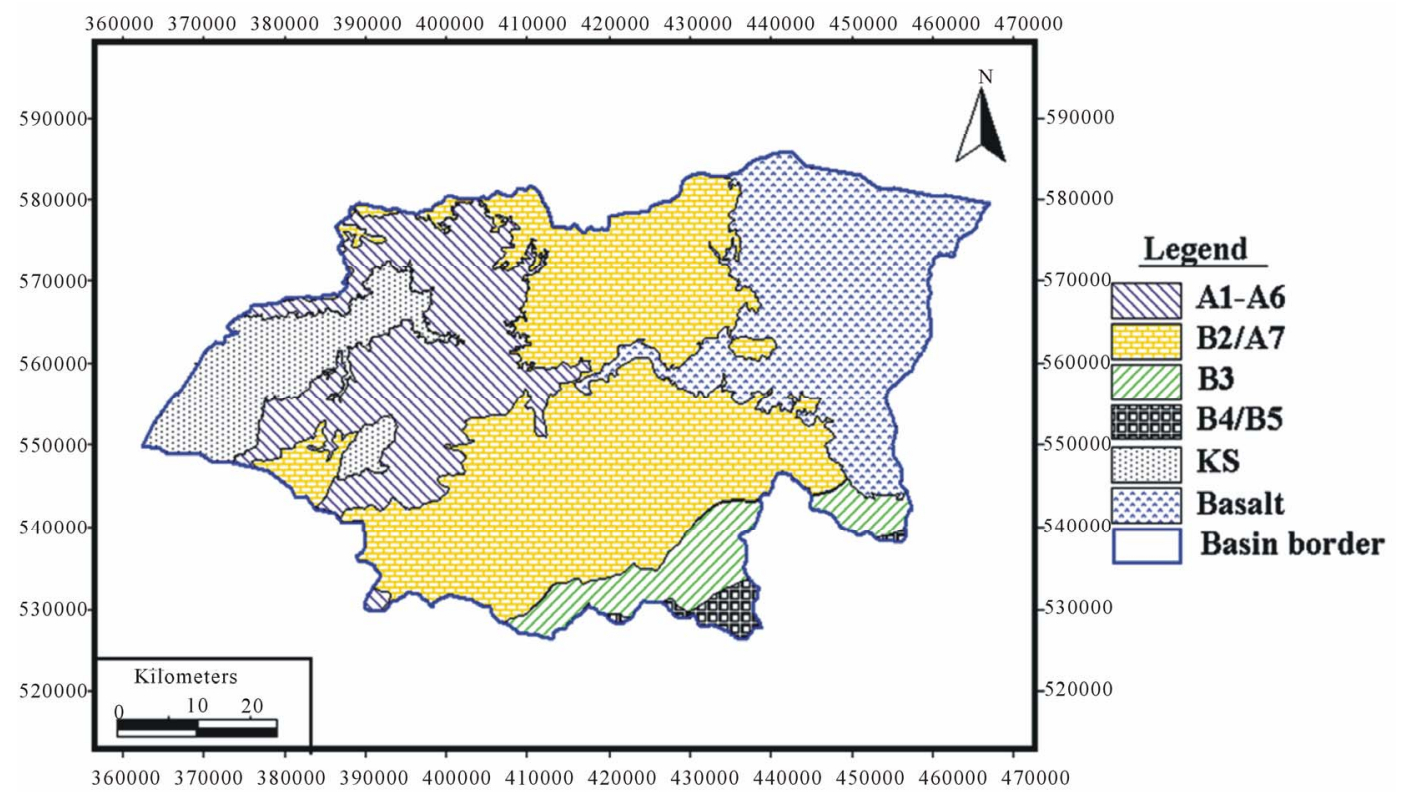

Figure 5. Hydrogeological map of the study area (modified after [10]). 
Belqa Groups represent the main aquifers in the study area. The Ajlun Group yields water generally from limestone and dolomitic limestone, while the Belqa group drains its water from the limestone and chert horizons. The A1/2 a confined aquifer and separated from A4 by a thick bed of Fuheis marl aquifer (A3) (Table 2). Two subunits are recognized within this aquifer: the lower part (A1) consisting of marls and ranging in thickness between 60 to $120 \mathrm{~m}$, and forming the confining layer that separates the A1/2 from the underlaying Kurnub Sandstone Aquifer. The upper part (A2) consists of thick limestone layer with a thickness ranging between 100 to $150 \mathrm{~m}$ [12].

The lower Aquifer Complex, with a thickness increases from south to north, consists of sandstone interrupted by thin layers of marl and limestone from the lower Cretaceous. According to Salameh and Udulft [20], the thickness is about $600 \mathrm{~m}$ with a general groundwater movement towards the west. The lower aquifer system consists of the Kurnub Group with a maximum thickness of about $300 \mathrm{~m}$ (Bender, 1974). It crops out in the north of the upper AZB, and encounters at a depth of about 480 $\mathrm{m}$ south of Amman, and at $530 \mathrm{~m}$ near Zerqa. It is a semi-confined aquifer which underlies the carbonate aquifers and separated by the marls and shales of Na'ur formation with a thickness of about $100 \mathrm{~m}$.

The hydrogeology of the study area is controlled by the dominant geological structures which affect water level, movement and occurrence of groundwater. The principal factors in determining the potential waterbearing areas are the permeability and secondary porosity both of which are directly related to the structure [12]. Groundwater occurs mostly in fractured and cavernous limestone, fractured chert; sandstone voids and wadi fill deposits, which are extracted from four aquifer systems.

\section{Materials and Methods}

One of the most widely used models to assess groundwater vulnerability to a wide range of potential contaminants is DRASTIC [21-26]. One advantage of using DRASTIC is that the inputs required for its application are generally available or easy to obtain from public agencies.

A DRASTIC model applied in a GIS environment has been used to evaluate the vulnerability of the AZB. It is based on the concept of the hydrogeological setting that includes the major geologic and hydrologic factors affecting and controlling the groundwater movement into, through and out of an area [27]. The DRASTIC stands for the seven parameters used in the model which are: Depth to water that mean the depth from the ground surface to the water table, deeper water table levels imply lesser chance for contamination to occur. Net Recharge represents the amount of water, which penetrates the ground surface and reaches the water table; recharge water represents the vehicle for transporting pollutants. Aquifer media refers to the saturated zone material properties, which controls the pollutant attenuation processes. Soil media represents the uppermost weathered portion of the unsaturated zone and controls the amount of recharge that can infiltrate downward. Topography refers to slope or steepness; areas with low slope tend to retain water for longer; this allows a greater infiltration of recharge of water and a greater potential for contaminant migration. Impact of the vadose zone (the unsaturated zone material) controls the passage and attenuation of the contaminated material to the saturated zone. The hydraulic conductivity indicates the ability of aquifer formation to transmit water; an aquifer with high conductivity is vulnerable to substantial contamination (Table 3).

DRASTIC assigns a rating to each parameter, on a scale of 1 to 10, based on functional curves. This rating is then scaled by a weighting factor, and the weighted ratings are summed to obtain the DRASTIC index (DI). The parameters are weighted according to their relative susceptibility to the pollutant. Each DRASTIC parameter has been assigned a relative weight ranging from 1 to 5 , according to their relative susceptibility to pollutants. The most significant parameters have weights of 5 , and the least significant is assigned a weight of 1 (Table 4).

Each of the seven DRASTIC parameters is mapped and classified either into ranges or into significant media types, which have an impact on pollution potential. Each factor or parameter is assigned a subjective rating. Weight multipliers are then used for each factor to balance and enhance its importance. The final vulnerability map is based on the DRASTIC index (DI) which is computed as the weighted sum overlay of the seven layers using the following equation:

$$
\begin{aligned}
\mathrm{DI}= & \mathrm{Dr} * \mathrm{Dw}+\mathrm{Rr} * \mathrm{Rw}+\mathrm{Ar}^{*} \mathrm{Ar} \\
& +\mathrm{Sr}^{*} \mathrm{Sw}+\mathrm{Tr} * \mathrm{Tw}+\mathrm{Ir}^{*} \mathrm{Iw}+\mathrm{Cr} * \mathrm{Cw}
\end{aligned}
$$

where $\mathrm{D}, \mathrm{R}, \mathrm{A}, \mathrm{S}, \mathrm{T}, \mathrm{I}$, and $\mathrm{C}$ are the seven parameters, $\mathrm{r}$ is the rating value and $w$ is the weight associated with each parameter. Once the DRASTIC Index has been computed, it is possible to identify areas which are more likely to be susceptible to groundwater contamination relative to one another. The higher the DRASTIC Index, the greater the groundwater pollution potential. These seven sets of data layers were digitized and converted to raster data sets that were processed using integrated ArcGIS 9.2.

In the DRASTIC method, it is assumed that: 1) the contaminant is introduced at the ground surface; 2) the contaminant is flushed into the groundwater by precipitation; 3 ) the contaminant has the mobility of water; and 4) the area evaluated is 100 acres or larger [26]. Furthermore, 
Table 3. DRASTIC parameters used in the study [27].

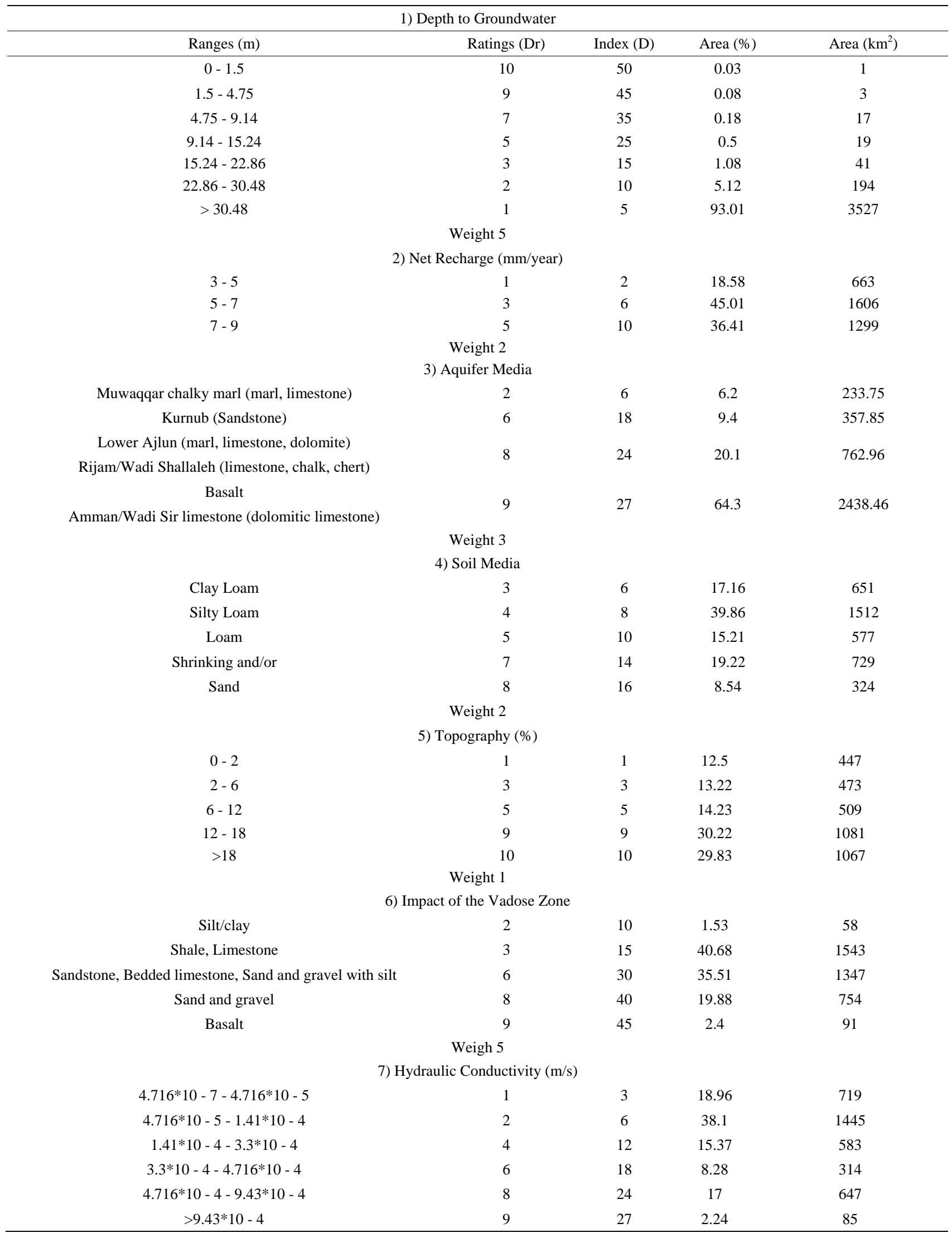


the numerical weights and ratings, which were established using the Delphi technique [27] are well defined and have been used worldwide [3,4,25,28-33]. The Delphi technique utilizes the practical and research experiences of professionals in the area of interest to assess levels of risk. The sources for the seven factors are presented in (Table 5).

\section{Results and Discussion}

The depth of the water table of 769 observation and production wells located in the AZB was obtained from WAJ [10]. The depth to the water table in the B2/A7 aquifer is less than $145 \mathrm{~m}$ in the most outcrop areas of the aquifer, whereas in the basaltic aquifer, the depth ranges from 174 - $223 \mathrm{~m}$ in the western parts to about $100 \mathrm{~m}$. This makes the western part of the basin more susceptible to contamination. The rating scores range between 1 and 10. The depth-to-water table interval range, DRASTIC rating, weight, and the resulting index are shown in Table $\mathbf{4}$ and Figure 6. Areas with high water tables are vulnerable because pollutants have short distances to travel before contacting the groundwater. Thus, the deeper the groundwater, the smaller the rating value.

Net Recharge map is generated from an equation which

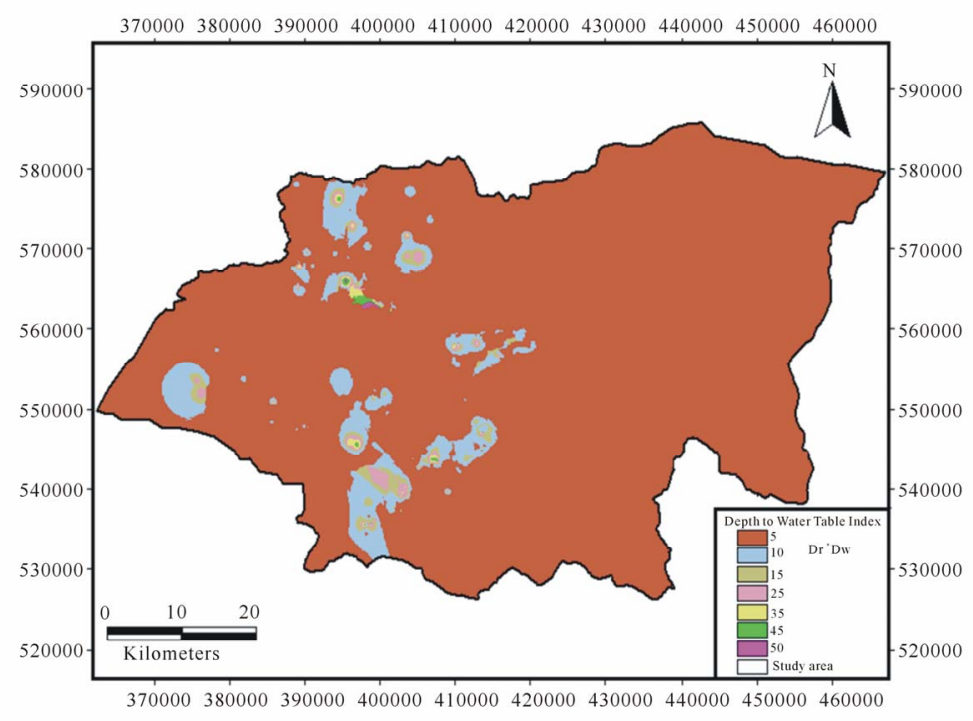

Figure 6. Map index of depth to groundwater table of the study area.

Table 4. The recharge ratings and weightings for the study area: (a) Slope; (b) Rainfall; (c) Soil permeability; and (d) Recharge value) $[4,34]$.

\begin{tabular}{|c|c|c|c|c|c|c|c|}
\hline Slope \% & Factor & Rainfall (mm) & Factor & Soil permeability $^{*}$ & Factor & Range & Rating \\
\hline$<2$ & 4 & $<500$ & 1 & Very slow & 1 & $11-13$ & 10 \\
\hline $2-10$ & 3 & $500-700$ & 2 & Slow & 2 & $9-11$ & 8 \\
\hline $10-33$ & 2 & $700-850$ & 3 & Moderate & 3 & $7-9$ & 5 \\
\hline \multirow[t]{2}{*}{$>33$} & 1 & $>850$ & 4 & Modrate-high & 4 & $5-7$ & 3 \\
\hline & & & & High & 5 & $3-5$ & 1 \\
\hline \multicolumn{2}{|c|}{$\mathrm{a}$} & \multicolumn{2}{|c|}{$\mathrm{b}$} & c & & \multicolumn{2}{|c|}{$\begin{array}{c}\mathrm{d} \\
\text { Weight } 2\end{array}$} \\
\hline
\end{tabular}

"Soil permeability is based on [33].

Table 5. Data for the DRASTIC index.

\begin{tabular}{cc}
\hline Data Source & Criteria \\
\hline WAJ, 2006 & Depth to groundwater \\
WAJ, 2006; MOA, 2005; NRCS & Net Recharge \\
WAJ, 2006 & Aquifer media \\
MOA, 2005 & Soil media \\
DEM from 90 meter resolution (Aster DEM) & Topography \\
WAJ, 2006; NRA, 2006 & Impact of Vadoze zone \\
WAJ, 2005 & Hydraulic Conductivity \\
\hline
\end{tabular}


calculates the ability of an area to act as a recharge zone relative to other areas. The factors used to generate the recharge map for the study area include slope, soil permeability and rainfall [24].

In order to calculate the recharge value (Rr*Rw), a digital elevation model (DEM) of the study area was used with $90 \mathrm{~m}$ resolution. The slopes in the study area (Figure 7(a)) were then derived from the DEM and classified according to the criteria given in Table 4(a).

The resulting slope map was converted into a grid coverage considering that the pixel values in this grid coverage are based on the slope ratings. The soil map was classified into two classes based on the criteria given in Table 4(c) and was then converted into grid coverage. Figure 7(b) shows the resulting map of the rainfall distribution as a factor in the recharge in the study area. Rainfall ranges from 50 - $500 \mathrm{~mm} /$ year, which gives the value of 1 for the recharge factor. The rainfall in the southwest part of the basin is of the range $>500 \mathrm{~mm} /$ year

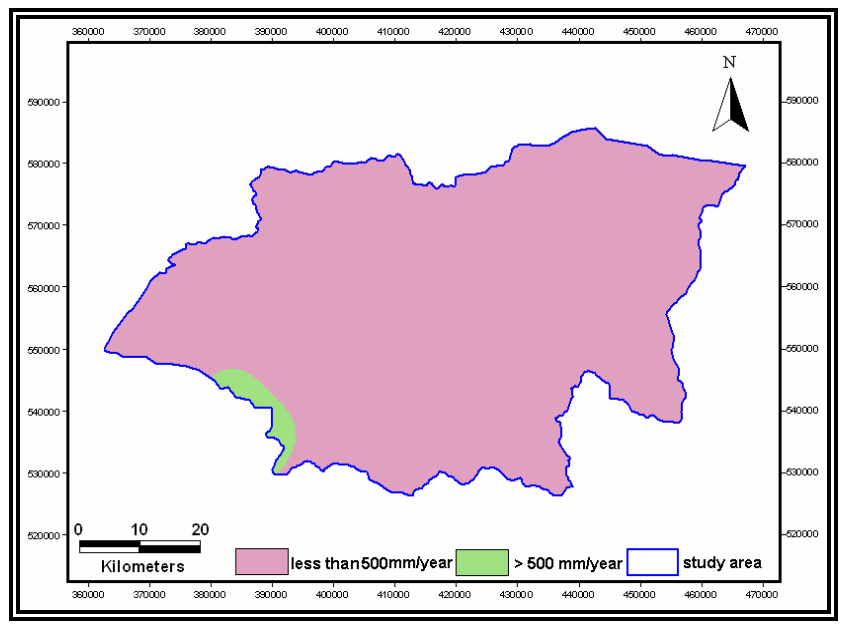

(a)

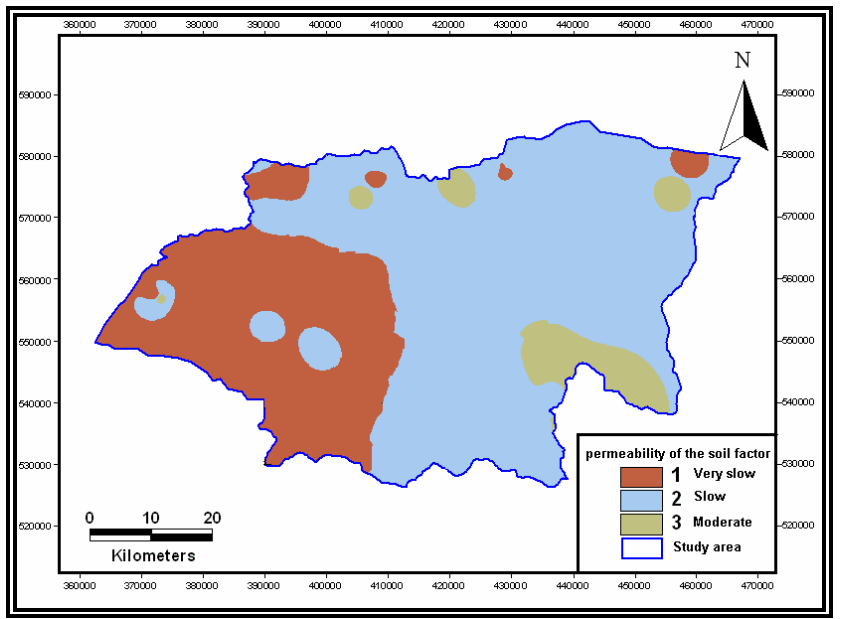

(c) and gives the value of 2 for a (Table 4(b)).

The following equation is used to generate a recharge value. This recharge value is then grouped into a range of values that are given a rating for use in the final DRASTIC calculation [24]. By applying Equation (1) to the study area, the ratings for recharge were calculated as shown in Table 4.

$$
\begin{aligned}
& \text { Recharge value } \\
& =\text { Slope } \% \text { + Rainfall + Soil permeability }
\end{aligned}
$$

The resulting map was then classified according to the criteria given in Table $\mathbf{4}$ and multiplied by the weighting factor of the recharge parameter as shown in Figure 7(d).

Most vulnerable areas have a value of 4 for the slope factor with the interval of less than 2\% (reflects areas with gentle slope). Most of the study area is within slope interval range from $10 \%$ to $33 \%$. The value of 3 is given to the slope interval rating ranging from $2 \%$ to $10 \%$,

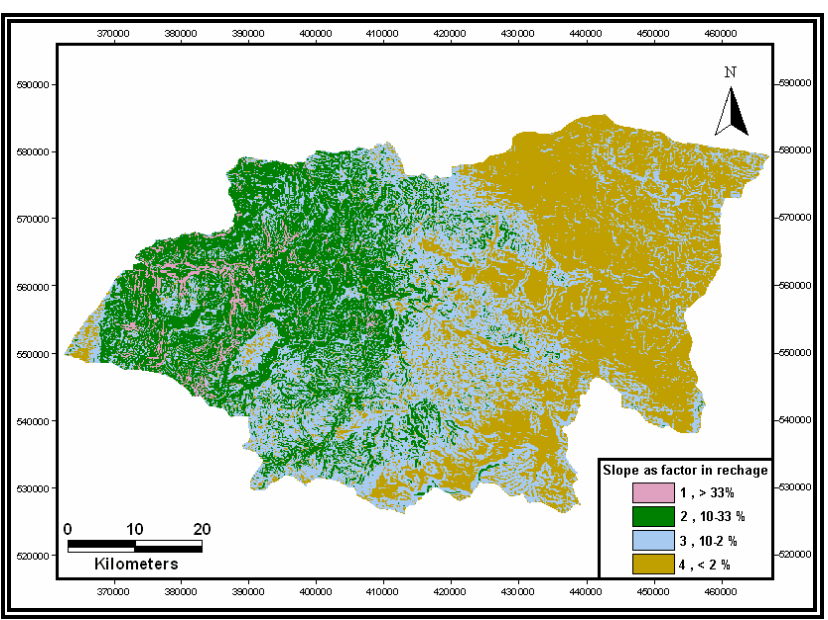

(b)

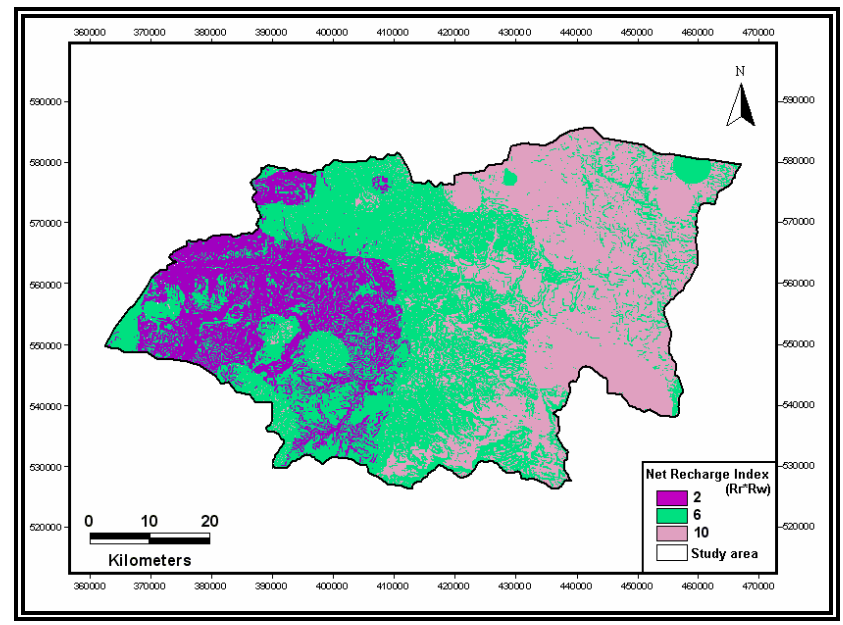

(d)

Figure 7. Maps of the rainfall distribution as a factor in recharge (a); the slope factor in recharge (b); the permeability soil factor in recharge (c); and the spatial distribution of the net recharge index (d) of study area. 
where the safest value of 2 is the thematic value in these areas as shown in Figure 7(d).

Figure 7(c) shows the soil permeability as a factor in recharge calculation. The area of study was classified into three classes: very slow, slow and moderate, where the slow soil permeability was assigned the value of 2 , the very slow has the value of 1 , and the moderate soil permeability was given the value of 3 . The rating of the recharge factor in the study area has three values $(1,3,5)$, where the value 1 reflects the minimum recharge rate due to its minimum rainfall amount, high slope percent, and slow permeability. The high value of 5 shows the higher recharge ability. The ratings were multiplied by the weighting factor of 2 to produce the spatial distribution of the recharge index (Figure 7(d)). Table 4 illustrates the distribution of the recharge rate. $18.6 \%$ of the study area has the value of $1 \%, 45.0 \%$ has the value of 3 , while $36.4 \%$ of the study area has the value of 5 .

Aquifer media govern the route and path length (groundwater flow system), and influence the amount of effective surface area of materials with which the contaminant may come in contact with the aquifer. Four types of an aquifer system occurred in the study area: the A4 which forms the middle aquifer in the northern basin (Figure 4), the B2/A7 represents the upper most aquifer in the central area. The Basalt aquifer ( $\mathrm{Z}$ ) forms the upper aquifer in the eastern area and Kurnub aquifer (K) which constitutes the lower aquifer in the western part of the study area (Figure 4). The A4 is composed mainly of limestone, chalk and chert, while the B2/A7 consists of limestone, dolomitic limestone and chert. The aquifer media is assigned a weight of 3 [27]. Figure 8(a) shows the aquifer media index computed by multiplying aquifer rating (Ar) and aquifer weighting (Aw) in study area. Table 5 illustrates the ratings and the composition of the aquifer media in the study area.

As shown in Table 3 (Section 3) the rating value of 2

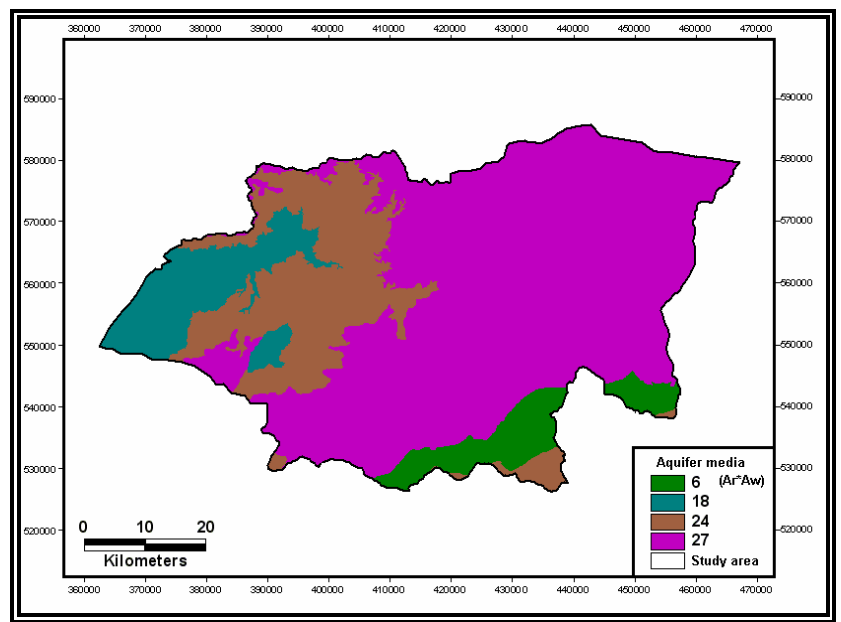

covers $6.2 \%$ of the study area, the value of 6 accounts for $9.4 \%$ of the study area. The value of 8 constitutes $20.1 \%$ of the study area, while $64.3 \%$ of the study area has a value of 9 . Soil has a significant impact on the amount of recharge, which can infiltrate to the water table, and hence on contaminant movement. The soil map of the study area (scale 1:50000) obtained from the Ministry of Agriculture, Jordan, where 19 soil units have been identified. The major soil types are: clay, clay loam, loam, silty clay, silty clay loam, sandy clay loam, in addition to some areas in which the soil is absent.

The soil media layer of the study area is reclassified by assigning a rating value to each soil class. These values range from 3 to 8 . Soil ratings were multiplied by soil weighting of 2 to produce the soil index map (Figure 8(b)). Table 3 (Section 4) shows the distribution of soil media rate in the study area. The rating value of 3 accounts for about $17.2 \%$ of the total area. The value of 4 comprises about $39.9 \%$ of the study area. The value of 5 covers $15.2 \%$ of the study area. The value of 7 constitutes $19.2 \%$ and the value of 8 covers around $8.5 \%$ of the study area.

Topography helps control the likelihood that a pollutant will run off or remain long enough to infiltrate through the ground surface [24]. 0\% - 2\% slope provides the greatest opportunity for a pollutant to infiltrate. Neither the pollutant nor precipitation exits the area as runoff. On the other hand, 18\% slope provides a high runoff capacity and a lesser probability of contaminant infiltration (high erosion and contamination of surface water) [35].

Slope percentages for the study area were calculated using the DEM data with a $90 \mathrm{~m}$ pixel resolution. Figure 9(b) shows the hillshade from DEM and the slope percentage of the study area. The slope was then classified and rated for use in the topography component map. The slope degree in the study area ranges between 0 - 44 . There are five classes of slope percentage that have a

Figure 8. Index maps of the aquifer media (a) and the soil media (b).

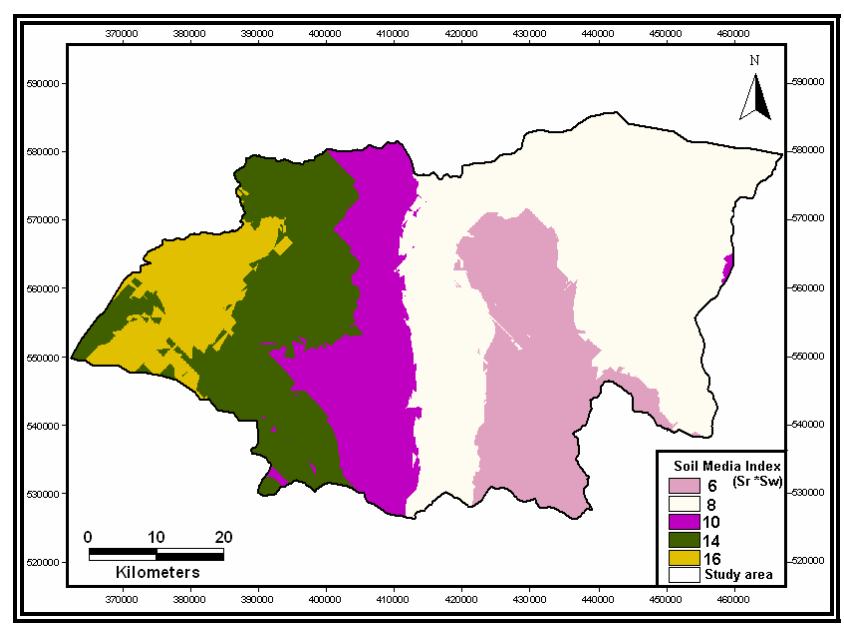




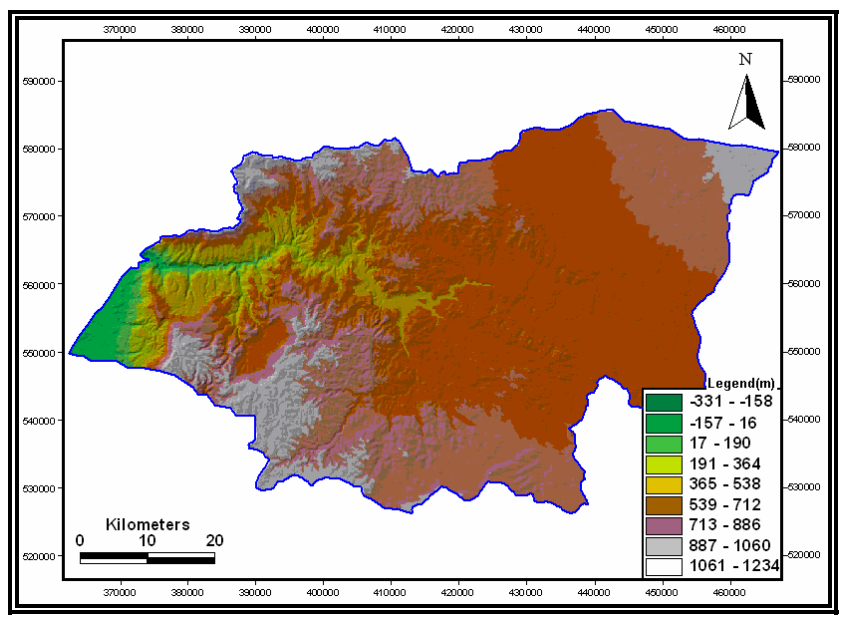

(a)

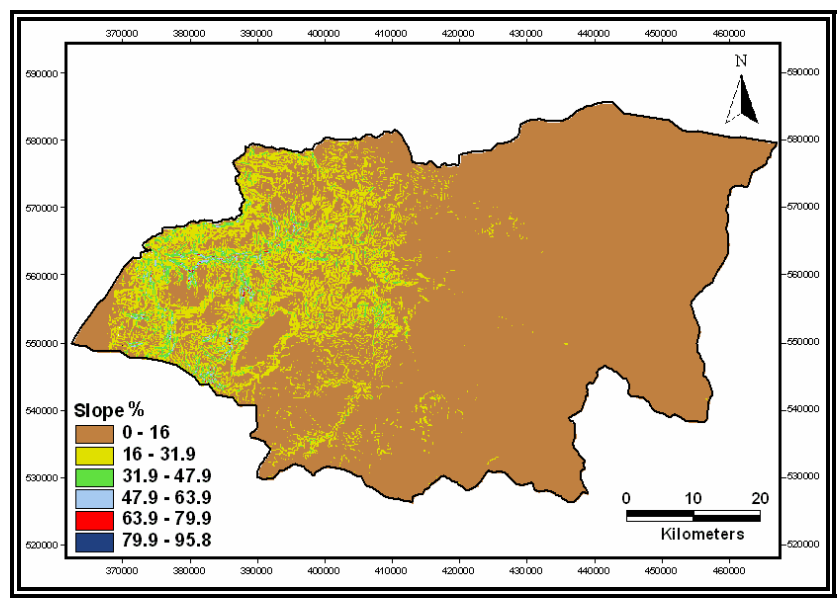

(c)

Figure 9. Maps of (a) DEM; (b) the Hillshade DEM;

range from 0 to more than $18 \%$ and ratings between 1 and 10 (Table 4). The rating 1 was assigned to the highlands' area in the western part where slopes are greater than $18 \%$, while the rating of 10 was given to the eastern part and the bottom of the southeastern area. The rating multiplied by the slope weight (1) produced the slope index map (Figure 9(d)).

Table 5 shows the distribution of topography rates in the study area. The topographic factor was assigned the rating values of $1,3,5,9,10$, and accounts for an area of about $12.5 \%, 13.2 \%, 14.2 \%, 30.2 \%$ and $29.4 \%$ of the study area, respectively. Most of the slope in the study area ranges from $0 \%$ - 6\% for the rate 9 and 10 in the eastern area, the bottom of the southeastern part and the central part of the study area.

According to Aller et al. [27], the vadoze media for an unconfined aquifer system is the same as the aquifer media. In other words, the DRASTIC methodology allows any standard geologic map, which depicts the distribution of lithologic units, to be used as a measure of the impact of the vadoze zone. The ratings for each vadoze

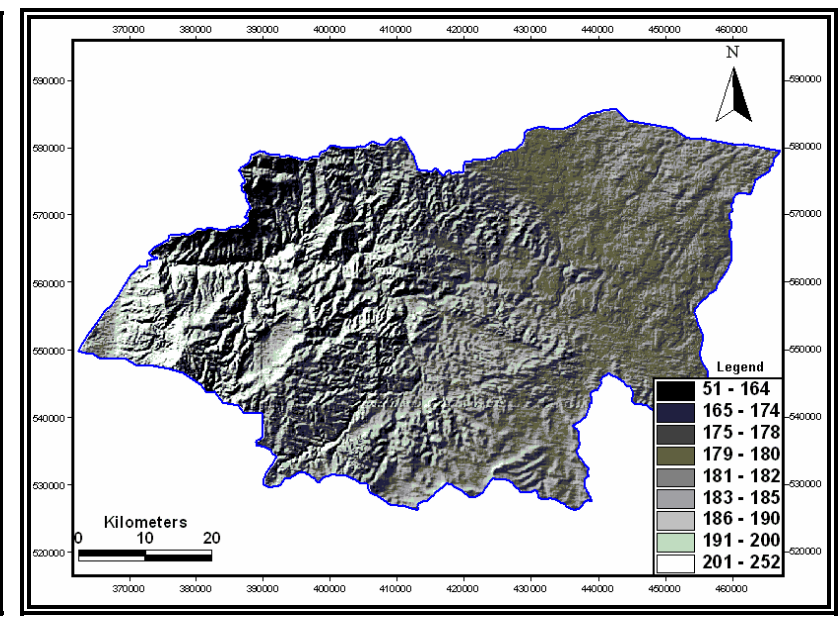

(b)

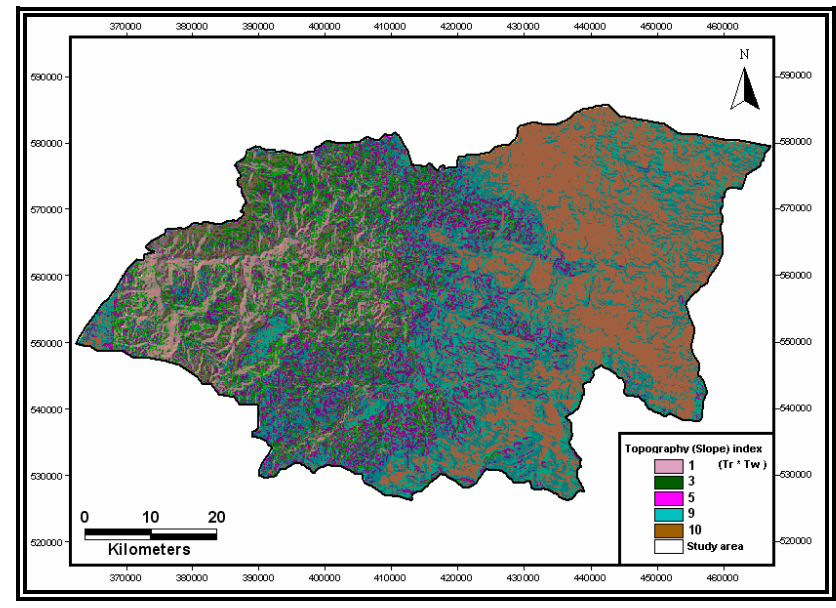

(d)

(c) slope; and (d) the topography index of study area.

zone material are illustrated in Table 3 (Section 6).

The vadoze zone stratigraphy was obtained from lithological columns taken from 55 wells drilled by the Ministry of Water and Irrigation in Jordan. This is important to determine the type of layers of low permeability (limiting factor layer) above the water table. The rates were given for each layer in each well and then the grid was built. About $40.7 \%$ of the study area has a rating value of 3 , while the rating value of 6 covers an area of about $35.5 \%$. Table 3 (Section 6) illustrates area distribution of vadoze zone rating of the study area. The ratings were multiplied by the weight of vadoze zone parameter (5) to produce the vadoze zone index map (Ir*Iw) (Figure 10(a)).

Hydraulic Conductivity values were obtained from aquifer pumping tests were calculated and modeled. The ranges and ratings of the hydraulic conductivity parame ter are listed in Table 3 (Section 7). Figure 10(b) shows the resulting map of the hydraulic conductivity index (Cr*Cw). 


\section{Drastic Vulerability Index of Amman-Zerqa Ground Water Basin}

The calculated DRASTIC index identifies areas, which are likely susceptible to groundwater contamination relative to each other. The maximum DRASTIC value is 210 and the minimum is 24. The higher DRASTIC index value, the greater the relative groundwater contamination potential. The DRASTIC index were further divided into five categories: No vulnerable (24 - 61), low (62 - 99), moderate (100 - 137), high (138 - 175) and very high (>175) (Table 6). Sites with high and very high categories are more vulnerable to contamination, consequently, need to be managed more closely, whereas sites with low pollution potential are less susceptible to groundwater contamination.

The final DRASTIC vulnerability thematic map was obtained by running the model in the geographic information system (GIS) environment by using the seven hydro-geological data layers to calculate a pollution potential index. The DRASTIC scores obtained from the model vary from 47 to 159 . These values were reclassified into three classes using the quantile classification scheme, i.e., low vulnerable zones, moderate vulnerable zones and high vulnerable zones (Table 6 and Figure 11).

The results showed that of the total $3792 \mathrm{~km}^{2}$, an area of about $45 \mathrm{~km}^{2}(1.19 \%)$ lies in the "no vulnerable zone" with DRASTIC index ranges between 47 and 75 , whereas $2624 \mathrm{~km}^{2}$ are located in the "low vulnerable zone" with a DRASTIC index ranging between 76 and 103. The vulnerability map shows about $69.2 \%$ of the area is classified as having low pollution potential and about $1120 \mathrm{~km}^{2}$ are within the "moderate vulnerability zone” with a DRASTIC index ranging between 104 and 131. Only $0.08 \%\left(3 \mathrm{~km}^{2}\right)$ of the study area lies under the area of high pollution potential (high vulnerability zone) with a DRASTIC index ranging between 132 and 159.

These results suggest that slightly one third of the AZB is at moderate risk in terms of pollution potential. These areas are mainly in the north-east and central parts of the basin where the physical factors like gentle slope and high water table are very well supporting the chances of getting shallow aquifer water polluted. It is noteworthy that the proposed location of the atomic power plant lies in the central basin within the "moderate vulnerability zone”. The areas, which are under the high vulnerable pollution, are mainly the central of Amman old city.

\section{Conclusions}

This study focuses on the assessment of aquifer vulnerability at AZB area. Based on the existing data, it was possible to derive an overall generalized assessment of
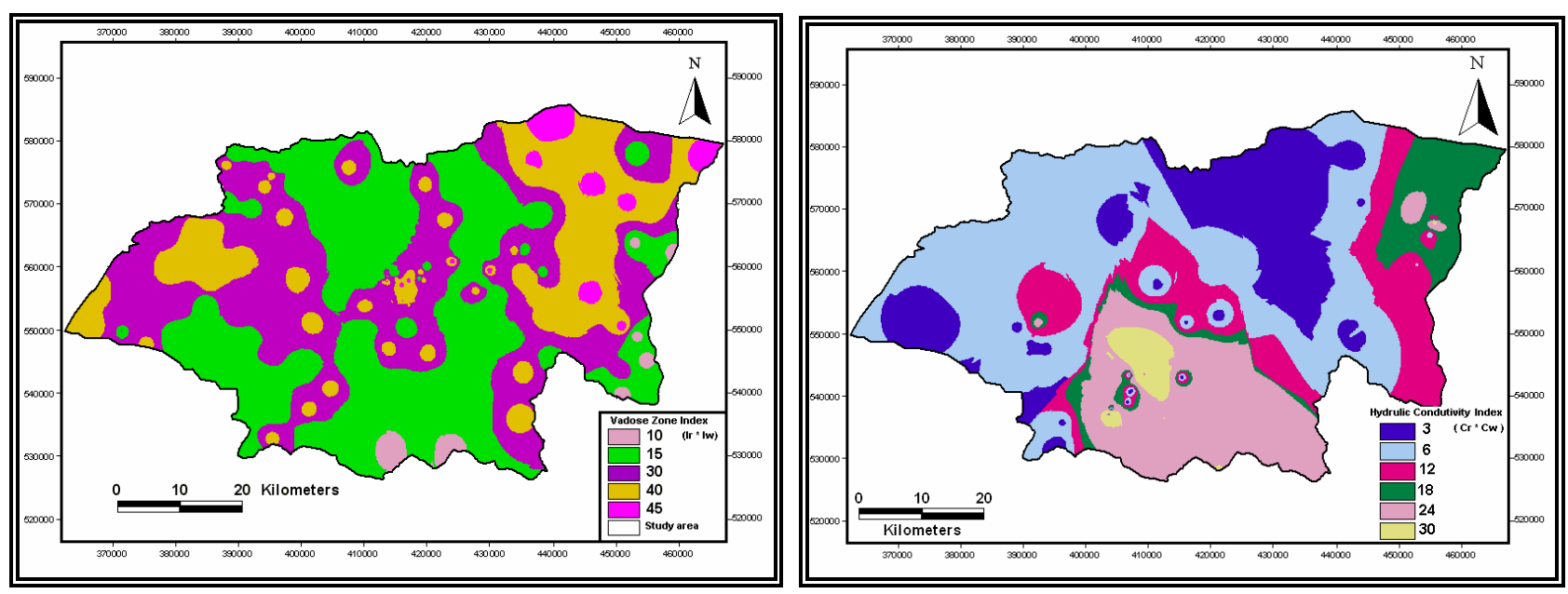

Figure 10. The vadoze zone index (a) and the hydraulic conductivity index (b) of study area.

Table 6. DRASTIC Index categories and the area under vulnerability to groundwater pollution in AZB.

\begin{tabular}{ccccc}
\hline Vulnerability Class & DRASTIC Index & Area $\left(\mathrm{km}^{2}\right)$ & Area $\%$ \\
\hline No & $24-61$ & 45 & 1.19 \\
Low & $62-99$ & 2624 & 69.20 \\
Moderate & $100-137$ & 1120 & 3 & 0.08 \\
High & $138-175$ & 3792 & 100 \\
\hline
\end{tabular}




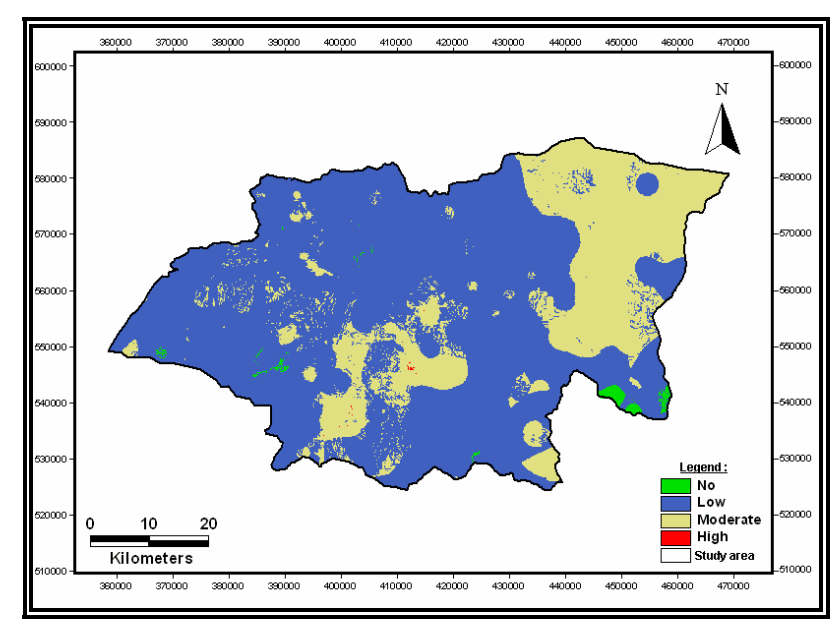

(a)

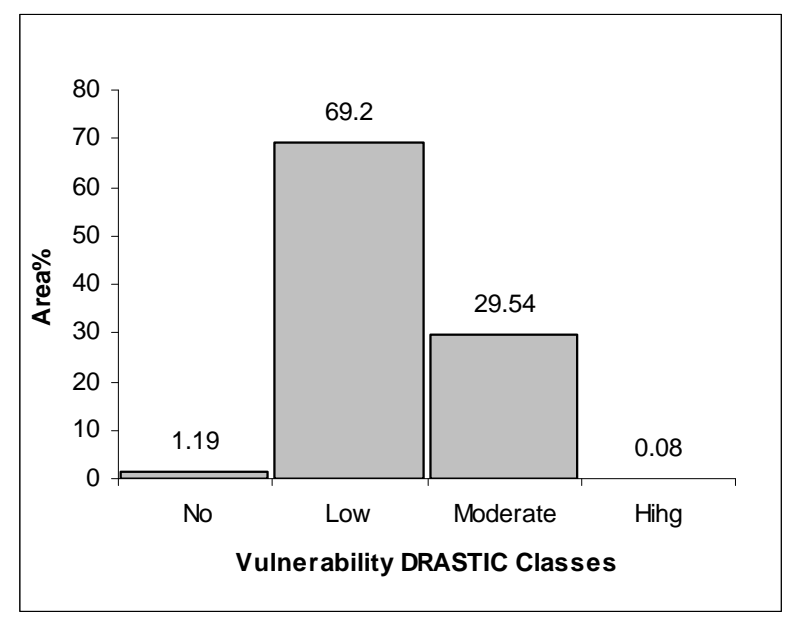

(b)

Figure 11. DRASTIC vulnerability map classes of groundwater and the DRASTIC classes and area percentage of the study area (b).

groundwater vulnerability. The DRASTIC mapping system allows the pollution potential of any area to be evaluated systematically using existing information. Vulnerability to contamination is a combination of hydrogeologic factors, anthropogenic influences, and sources of contamination in any given area. The DRASTIC system focuses only on those hydrogeologic factors that influence groundwater pollution potential. The system consists of two major elements: the designation of mappable units, termed hydrogeologic settings, and the superposition of a relative rating system to determine pollution potential. The main conclusions of this study can be summarized as follows: The final DRASTIC values have been grouped together into low, moderate, and high pollution potential classes. These classes represent the relative pollution potential within the study area. The vulnerability map shows approximately more than $69.18 \%$ of the area is classified as having low pollution potential with DRASTIC index values ranged between 65 - 96 . The No vulnerability DRASTIC indexes values ranged between 33 - 64 and it represent are area of $0.98 \%$. $29.61 \%$ are classified as having moderate pollution potential within DRASTIC index values range of 97 - 128, and $0.22 \%$ of the total area is classified as having a High pollution potential with DRASTIC index values ranging between 129 - 160 . These results suggest that slightly one third of the AZB is at moderate risk in terms of pollution potential.

These areas are mainly in the north-east and central parts of the basin where the physical factors like gentle slope and high water table are very well supporting the chances of getting shallow aquifer water polluted. It is noteworthy that the proposed location of the atomic power plant lies in the central basin within the "moderate vulnerability zone. The areas, which are under the high vulnerable pollution, are mainly the central of Amman old city. The recommendations of this study can be presented to minimize groundwater contamination and reduce the negative impacts on groundwater quality. The vulnerability of groundwater contamination made it absolutely necessary to local authorities for managing of groundwater resources and need to be closely monitored. Vulnerability assessments are recommended in order to delineate areas with high potential for specific contamination. Special attention should be paid to the areas with high pollution potential, where protection zones must be delineated.

\section{Acknowledgements}

The research presented has been financially supported by Luleå University of Technology, Sweden and by "Swedish Hydropower Centre-SVC”. SVC has been established by the Swedish Energy Agency, Elforsk and Svenska Kraftnät together with Luleå University of Technology, The Royal Institute of Technology, Chalmers University of Technology and Uppsala University. The support is highly appreciated.

\section{REFERENCES}

[1] DOS-Department of Statistics, "Estimation of population by Governorate,” Department of Statistics, Amman, 2003.

www.dos.gov.jo/sdb_pop_e/ehsaat/alsokan/1_2003.htm

[2] OPTIMA, "Optimization for Sustainable Water Resources Management,” 2004.

http://www.ess.co.at/OPTIMA/CASE/JO/Zerqa.html

[3] A. Margane, "Management and Protection and Sustainable Use of Groundwater and Soil Resources in the Arab Region, Volume 4: Guideline for Groundwater Vulnerability Mapping and Risk Assessment for Susceptibility of Groundwater Resources to Contamination,” Project No. 1996.2189.7, Federal Ministry for Economic Cooperation 
and Development, Bonn, 2003.

[4] R. Al-Adamant, I. Foster and S. Baban, "Groundwater Vulnerability and Risk Mapping for the Basaltic Aquifer of the Azraq Basin of Jordan Using GIS, Remote Sensing and DRASTIC,” Applied Geography, Vol. 23, No. 4, 2003, pp. 303-324. doi:10.1016/j.apgeog.2003.08.007

[5] A. El-Naqa, “Aquifer Vulnerability Assessment Using the DRASTIC Model at Russeifa Landfill, Northeast Jordan,” Environmental Geology, Vol. 47, No. 1, 2004, pp. 51-62. doi:10.1007/s00254-004-1126-9

[6] M. Al Kuisi, A. El-Naqa and N. Hammouri, "Vulnerability Mapping of Shallow Groundwater Aquifer Using SINTACS Model in the Jordan Valley Area, Jordan,” Environmental Geology, Vol. 50, No. 5, 2006, pp. 645-650. doi:10.1007/s00254-006-0239-8

[7] H. Werz and H. Hötzl, "Groundwater Risk Intensity Mapping in Semi-Arid Regions Using Optical Remote Sensing Data as an Additional Tool," Hydrogeology Journal, Vol. 15, No. 6, 2007, pp. 1031-1049. doi:10.1007/s10040-007-0202-0

[8] N. Hammouri and A. El-Naqa, "GIS based Hydrogeological Vulnerability Mapping of Groundwater Resources in Jerash Area-Jordan,” Geofísica Internacional, Vol. 47, No. 2, 2008, pp. 85-97.

[9] M. Awawdeh and R. Jaradat, "Evaluation of Aquifers Vulnerability to Contamination in the Yarmouk Basin, Jordan, Based on DRASTIC Method,” Jaradat Arabian Journal of Geosciences, Vol. 3, No. 3, 2010, pp. 273-282.

[10] Water Authority of Jordan, "WAJInternal Files for Groundwater Basins in Jordan,” 2006. http://www.mwi.gov.jo/sites/en-us

[11] M. Masri, "Report on the geology of the Amman-Zerqa area," Unpublished Report, Central Water Authority, Amman, 1963.

[12] M. MacDonald and Partners in Cooperation with Hunting Geological Surveys Limited: East Bank Water Resources, "East Bank Water Resources, Vol. 5,” Ministry of Water and Irrigation, Amman, 1965, p. 512.

[13] D. H. Parker, "The Hydrogeology of the Mesozioc-Cainozoic Aquifer of the Western Highlands and Plateau of East Jordan,” Food and Agriculture Organization (FAO), Rome, 1970.

[14] VBB - Vatten Byggnads Bryan, FAWZI and Associates, "Water Resources Study for Amman Water Supply, Vol. 1 and 2," Water and Sewerage Authority of Jordan, Stockholm in association with FAWZI and Associates, Amman, 1977. (Unpublished)

[15] Agrar, Hydrotechnik Gmbh and GTZ, "National Water Resources Master Plan of Jordan, Vol. 7," Ministry of Planning/Documentation Section, Amman, 1977.

[16] Howard Humphreys and Sons, "Water Use Strategy North Jordan. Summary Report," National Planning Council, The Hashemite Kingdom of Jordan, Amman, 1978.

[17] J. Al Mahamid, "Integration of Water Resources of the Upper Aquifer in Amman-Zerqa Basin Based on Mathematical Modeling and GIS, Jordan,” Ph.D. Thesis, University of Jordan, Amman, 2005.
[18] S. Mikbel and W. Zacher, "The Wadi Shuieb Structure in Jordan,” Neues Jahrbuch für Geologie und Paläontologie, Monatshefte, Vol. 9, 1981, pp. 571-576.

[19] W. Barber, "An Outline for Water Planning in East Jordan,” Natural Resources Authority, Jordan, 1975.

[20] E. Salameh and P. Udluft, "The Hydrodynamic Pattern of the Central Part of Jordan,” Geologisches Jahrbuch Reihe C, Vol. 38, 1985, pp. 39-55.

[21] B. M. Evans and W. L. Mayers, “A GIS-Based Approach to Evaluating Regional Groundwater Pollution Potential with DRASTIC,” Journal of Soil and Water Conservation, Vol. 45, No. 2, 1990, pp. 242-245.

[22] T. G. Fritch, C. L. McKnight Jr., J. C. Yelderman and J. G. Arnold, "An Aquifer Vulnerability Assessment of the Paluxy Aquifer, Central Texas, USA, Using GIS and a Modified DRASTIC Approach,” Environmental Management, Vol. 25, No. 3, 2000, pp. 337-345. doi:10.1007/s002679910026

[23] R. C. Knox, D. A. Sabatini and L. W. Canter, "Subsurface Transport and Fate Processes,” Lewis Publishers, Boca Raton, 1993.

[24] G. Piscopo, "Groundwater Vulnerability Map, Explanatory Notes, Castlereagh Catchment," NSW Department of Land and Water Conservation, Parramatta, 2001.

http://www.dlwc.nsw.gov.au/care/water/groundwater/rep orts/pdfs/castlereagh_map_notes.pdf

[25] D. Rundquist, A. Peters, D. Liping, D. Rodekohr, R. Ehrman and G. Murray, "State-Wide Groundwater Vulnerability Assessment in Nebraska Using the DRASTIC/GIS Model," GeoCartography International, Vol. 6, No. 2, 1991, pp. 51-58.

[26] S. Secunda, M. Collin and A. J. Melloul, "Groundwater Vulnerability Assessment Using a Composite Model Combining DRASTIC with Extensive Land Use in Israel's Sharon Region,” Journal of Environmental Management, Vol. 54, No. 1, 1998, pp. 39-57. doi:10.1006/jema.1998.0221

[27] L. Aller, T. Bennett, J. H. Lehr, R. J. Petty and G. Hackett, "DRASTIC: A Standardized System for Evaluating Groundwater Pollution Potential Using Hydrogeologic Settings," US Environmental Protection Agency Report 600/2-87/035, US Environmental Protection Agency, Washington DC, 1987.

[28] M. Anwar, C. Prem and V. B. Rao, "Evaluation of Groundwater Potential of Musi River Catchment Using DRASTIC Index Model,” In: B. R. Venkateshwar, M. K. Ram, C. S. Sarala and C. Raju, Eds., Proceedings of the International Conference on Hydrology and Watershed Management, B. S. Publishers, Hyderabad, 2003, pp. 399-409.

[29] I. Babiker, M. Mohammed, T. Hiyama and K. Kato, “A GIS-Based DRASTIC Model for Assessing Aquifer Vulnerability in Kakmigahara Heights, Gifu Prefecture, Central Japan," Science of the Total Environmental, Vol. 345, No. 1-3, 2005, pp. 127-140. doi:10.1016/j.scitotenv.2004.11.005

[30] H. Chandrashekhar, S. Adiga, V. Lakshminarayana, C. J. Jagdeesha and C. Nataraju, "A Case Study Using the Model 'DRASTIC' for Assessment of Groundwater Pol- 
lution Potential," Proceedings of the ISRS National Symposium on Remote Sensing Applications for Natural Resources, Indian Society of Remote Sensing, Bagalore, 19-21 June 1999, pp. 414-417.

[31] B. Dixon, "Groundwater Vulnerability Mapping: A GIS and Fuzzy Rule Based Integrated Tool,” Applied Geography, Vol. 25, No 4, 2005, pp. 327-347. doi:10.1016/j.apgeog.2005.07.002

[32] P. Napolitano and A. Fabbri, "Single-Parameter Sensitivity Analysis for Aquifer Vulnerability Assessment Using DRASTIC and SINTACS," Hydrology and Water Resources Management, Vol. 235, 1996, pp. 559-566.
[33] S. Shahid, "A Study of Groundwater Pollution Vulnerability Using DRASTIC/GIS, west Bengal, India,” Journal of Environmental Hydrology, Vol. 8, No. 11-12, 2000, p. 124.

[34] USDA (United State Department of Agriculture), "Permeability Key,” Agriculture Handbook, Vol. 436, US Government Printing Office, Washington DC, 1994. http://www.mn.nrcs.usda.gov/mo10/mo10guides/permkey

[35] A. D. Davis, A. J. Long and M. Wireman, "KARSTIC: A Sensitivity Method for Carbonate Aquifers in Karst Terrain,” Environmental Geology, Vol. 42, No. 1, 2002, pp. 65-72. doi:10.1007/s00254-002-0531-1 